\title{
LEGENDA SYEKH MUHAMMAD ARSYAD AL-BANJARI DAN PENGARUHNYA PADA MASYARAKAT BANJAR
}

(The Legend of Syekh Muhammad Arsyad Al-Banjari and the Impact on Banjar Society)

\author{
Dede Hidayatullah \\ Balai Bahasa Provinsi Kalimantan Selatan \\ Jalan A. Yani km. 32,2 Loktabat Banjarbaru Kalimantan Selatan \\ 08125026715, Pos-el:dayatdh@gmail.com
}

Diterima 1 Oktober 2020

Direvisi 7 Oktober 2020

Disetujui 13 Oktober 2020

\section{https://doi.org/10.26499/und.v16i2.2838}

\begin{abstract}
Abstrak. Cerita para datu merupakan cerita dalam bentuk legenda yang menceritakan kiprah para datu dalam membina masyarakat dan menyebarkan ajaran Islam. Legenda Syekh Muhammad Arsyad al-Banjari merupakan cerita yang terdapat di Martapura yang mempunyai peranan penting dalam penyebaran agama Islam di Kalimantan Selatan. Penelitian ini akan membahas tentang legenda salah seorang datu yang menyebarkan agama Islam di Kabupaten Banjar, yaitu Syekh Muhammad Arsyad al-Banjari. Penelitian ini bertujuan menguraikan tentang mitos Syekh Muhammad Arsyad al-Banjari, mendeskripsikan perjalanan hidupnya dan keramat Syekh Muhammad Arsyad al-Banjari. Metode yang digunakan dalam penelitian ini adalah etnografi deskritif. Dengan metode akan diuraikan pengaruh yang muncul dari legenda Syekh Muhammad Arsyad al-Banjari pada budaya dan kehidupan masyarakat Banjar. Dengan menggunakan metode ini ditemukan bahwa legenda Syekh Muhammad Arsyad alBanjari telah membentuk karakter orang Martapura menjadi suka akan ilmu, peduli pada pembangunan sarana dan prasarana pendidikan, yaitu pesantren dan memandang keramat sebagai pelengkap keilmuan, bukan menjadi fokus dalam menuntut ilmu dan ibadah.
\end{abstract}

Kata kunci: Kata Kunci: legenda, karakter, pesantren, dan ilmu.

Abstract. The story of the datu is a story in the form of a legend that tells the role of the datu in developing society and spreading Islamic teachings. The legend of Syekh Muhammad Arsyad al-Banjari is a story from Martapura, which has an important role in the spread of Islam in South Kalimantan. This study will discuss the legend of one of the datu who spread Islam in Banjar Regency, namely Syekh Muhammad Arsyad al-Banjari. The objective of this study is to describe the myth of Syekh Muhammad Arsyad al-Banjari, the story of his life, and the sacredness of Syekh Muhammad Arsyad al-Banjari. Using the ethnographic descriptive method, it will reveal the influence that emerged from the legend of Syekh Muhammad Arsyad al-Banjari in the Banjar society. This method has shown that the legend of Syekh Muhammad Arsyad al-Banjari has shaped the character of the Martapura people. They like studying and care about the development of educational facilities and infrastructure, such as Islamic boarding schools, and view of sacredness as a part of science, not as a focus in studying and worship.

Keywords: legend, character, Islamic boarding school, and knowledge.

\section{PENDAHULUAN}

Suku Banjar mulanya bermukim di hulu aliran sungai Tabalong, yaitu daerah Tanjung Puri. Daerah ini merupakan koloni orang Melayu dari zaman awal Sriwijaya. Di daerah ini terjadi perpaduan jenis dan akulturasi budaya antara orang-orang Melayu, suku Maanyan, Lawangan, dan Dayak Bukit, ditambah suku Ngaju atau Biaju 
serta pedagang-pedagang dari Jawa pantai Utara yang melarikan diri karena adanya penaklukan oleh Mataram. Ketika kerajaan Banjar lahir tahun 1526, penduduknya merupakan campuran dari Ngaju, Melayu, Maanyan, Jawa, suku Bukit, dan suku lainnya yang diikat oleh agama Islam, menggunakan bahasa dan adat istiadat Banjar. Masyarakat ini kemudian berkembang membentuk tiga kelompok subsuku, yaitu (Banjar) pahuluan, (Banjar) Batang Banyu, (Banjar) Kuala. Banjar Pahuluan berasal dari kesatuan etnik Bukit, Banjar Kuala dari kesatuan Etnik Ngaju, dan Banjar Batang Banyu, dari kesatuan etnik Maanyan. (Sam`ani et al., 2004: 19, lihat juga Daud, 1997: 3) Dengan demikian, bentuk keislaman urang Banjar terdiri atas konsepsi-konsepsi yang berasal Melayu, pengaruh kepercayaan Hindu, dan warisan kepercayaan Dayak, yang menjadi pembentuk suku Banjar. Islam menjadi ciri dan identitas orang Banjar.

Masyarakat Banjar merupakan masyarakat agamis. Masyarakat yang memegang teguh keyakinan agamanya. Religiusitas urang Banjar ini tercermin dalam sastra lisannya seperti pantun, papadah, madihin, mantra, dan juga cerita rakyat. Cerita rakyat yang bercerita tetang Islam dan penyebar Islam pada masa lalu tesebar dalam legenda datu. Legenda Datu ini tersebar dari mulut ke mulut, dari generasi ke generasi sehingga mengakar kuat pada masyarakat Banjar.

Penyebaran legenda ini dan sastra lisan lainnya yang dilakukan secara lisan karena masyarakat Banjar merupakan masyarakat yang tidak mengenal aksara, kecuali sesudah abad ke-16. Pada abad ini, urang Banjar mulai mengenal aksara Arab yang digunakan untuk menuliskan bahasa Banjar yang sering disebut aksara Arab Melayu. Oleh karena itu, sangat jarang ditemukan cerita-cerita rakyat, pantun, dan sastra lisan lainnya yang sudah dalam bentuk tulisan, kecuali sebagian dari naskahnaskah lama peninggalan Syekh Muhammad Arsyad al-Banjari, dan naskah syair, serta beberapa naskah mantra-mantra yang masih disimpan oleh masyarakat Banjar.

Cerita para datu merupakan cerita dalam bentuk legenda yang menceritakan kiprah para datu dalam membina masyarakat dan menyebarkan ajaran Islam. Setiap daerah memiliki cerita para datu yang yang diyakini keberadaannya, seperti cerita Datu Kabul yang menyebarkan Islam dan membangun masjid di Sungai Banar Amuntai kabupaten Hulu Sungai Utara, cerita Datu Abbas di Wasah Kandangan Kabupaten Hulu Sungai Selatan, cerita Datu Sanggul di Kabupaten Tapin, cerita Syekh Muhammad Arsyad al-Banjari di Martapura Kabupaten Banjar, cerita datu Jamaluddin Sungai Jingah di Banjarmasin, dan lain-lain.

Para datu itu menyebarkan agama Islam di daerahnya dengan menggunakan metode dakwah yang berbeda-beda menyesuaikan dengan kondisi dan keadaan daerah tempat mereka berdakwah. Oleh karena itu, legenda para datu ini mengandung falsafah hidup dan kehidupan manusia dan serta nilai-nilai, seperti adat istiadat, kearifan lokal masyarakat, dan moral.

Selain itu, para datu tersebut masing-masing mempunyai karamah yang muncul sebagai solusi dalam menghadapi berbagai persoalan. Karamah ini muncul bukan sebagai bentuk pamer, tetapi sebagai jawaban atas persoalan yang sedang dihadapi oleh para datu. Karamah para datu itu 
berbeda-beda. Perbedaan itu muncul karena perbedaan persoalan yang dihadapi dan perbedaan kondisi sosial masyarakatnya.

Ada beberapa penelitian yang memfokuskan perhatian pada legenda antara lain, seperti Yulianto, Jahdiah, Suminar, \& Hidayatullah, (2005) menganalisis secara semiotik tentang tokoh mitos dan legendaris dalam sastra Banjar seperti Datu Ambulung, Datu Majuranta, Datu Yujung dan Datu Taksilu. Hasil penelitian menunjukkan bahwa cerita-cerita legenda dan mite itu mempunyai nilai moral dalam simbol dan makna cerita; Hidayatullah, (2017) meneliti tentang motif dan keramat legenda Datu Kabul, hasil penelitian menunjukkan bahwa Datu Kabul mempunyai dua motif, yaitu motif benda berupa mesjid Sungai Banar, dan motif perbuatan. Kedua motif terlihat pada keramat yang ada pada Datu Kabul. Keramat Datu Kabul ada empat, yaitu tubuhnya bercahaya, doanya selalu mustajab, bisa mendatangkan tiang kayu Kurma dari Mekkah untuk pembangunan mesjid Sungai Banar, dan tubuhnya menghilang ketika meninggal. Motif dan keramat Datu Kabul membuat masyarakat sekitarnya mempercayai dan memperlakukan Mesjid Sungai Banar seperti ka'bah, yaitu harus tawaf 7 kali ketika masuk masjid; Laila (2014) meneliti tentang fungsi cerita riwayat Datu Sanggul bagi masyarakat Banjar hasilnya adalah legenda Datu Sanggul diyakini kebenarannya oleh masyarakatnya dan berfungsi sebagai sistem proyeksi, sebagai alat pengesahan kebudayaan dan sebagai alat penekan berlakunya tata nilai masyarakat Banjar, serta sebagai alat pendidikan.

Penelitian ini akan membahas tentang legenda salah satu datu yang menyebarkan agama Islam di Kabupaten Banjar, yaitu Legenda Syekh Muhammad Arsyad al-Banjari atau Syekh Muhammad Arsyad al-Banjari, mitos, dan pengaruhnya terhadap masyarakat Banjar. Legenda Syekh Muhammad Arsyad al-Banjari dapat digolongkan ke dalam cerita rakyat yang dalam istilah Danandjaja (2002) termasuk dalam tiga golongan besar, yaitu 1) mite (myth), 2) legenda (legend), dan dongeng (foklor) (hlm. 50). Penelitian ini bertujuan untuk menguraikan tentang legenda Syekh Muhammad Arsyad al-Banjari, mendeskripsikan perjalanan hidupnya dan keramat Syekh Muhammad Arsyad al-Banjari. peneliti kemudian menguraikan pengaruh yang muncul dari legenda Syekh Muhammad Arsyad al-Banjari masyarakat Banjar.

Penelitian ini penting dilakukan karena legenda Syekh Muhammad Arsyad ini sudah mengakar dalam masyarakat di Kabupaten Banjar khususnya dan masyarakat di Kalimantan pada umumnya. Dengan metode etnografi deskritif akan diuraikan hubungan antara budaya masyarakat dengan legenda Legenda Syekh Muhammad Arsyad al-Banjari atau Syekh Muhammad Arsyad alBanjari.

Dewasa ini, dalam revolusi industri 4.0, semua informasi tersebar luas dalam berbagai media social berbasis online seperti facebook, instagram, youtube, dan whatsApp, banyak bermunculan tulisan dan video yang menceritakan tentang keramat seseorang. Tulisan dan video tentang keramat yang masif ini membuat pembaca dan penonton menganggap bahwa seakan-akan tujuan hidup itu adalah mempunyai keramat itu. Hal ini menyebabkan ada anggapan telah terjadi 
pengkultusan terhadap orang-orang yang mempunyai keramat. Selain itu, adanya segolongan umat yang tidak mempercayai adanya keramat. Kemudian terjadilah perdebatan yang panjang antara golongan yang mempercayai dan meyakini keramat itu ada dan golongan yang tidak mempunyai keramat. Hal ini bisa menyebabkan perpecahan diantara umat Islam. Oleh karena itu, penelitian ini juga akan mengupas tentang keramat Syekh Muhammad Arsyad al-Banjari, penyebab kemunculan keramat, fungsi dan kedudukan keramat. Selain sebagai legenda masyarakat Banjar, dalam hal ini masyarakat yang berada di sekitar wilayah Martapura khususnya dan Kalimantan pada umumnya, menganggap bahwa cerita Syekh Muhammad Arsyad merupakan cerita nyata yang diwariskan sebagai bagian tak terpisahkan dari masyarakatnya. Hal ini karena legenda Syekh Muhammad Arsyad ada hubungannya dengan peristiwa sejarah, yaitu pembuatan Sungai Tuan yang berfungsi sebagai irigasi untuk daerah Kalampayan dan sekitarnya, peninggalan kitab-kitab yang masih tersimpan rapi seperti kitab Sabilal Muhtadin, Tuhfaturragibin, dan kitabun Nikah. Selain itu, sesuai dengan pendapat Danandjaja (2002) Legenda Syekh Muhammad Arsyad ini dianggap oleh masyarakat pemilik cerita sebagai suatu kejadian yang sungguh-sungguh pernah terjadi (hlm. 66). Sebagaimana cerita Legenda para datu lainnya, legenda Datu Kabul juga mempunyai wujud berupa peninggalan, seperti kitab-kitab tulisan tangan Syekh Muhammad Arsyad alBanjari, keturunan Syekh Muhammad Arsyad yang melanjutkan dakwahnya tesebar di kawasan nusantara, mulai dari
Indonesia, Brunai Darussalam, Malaysia, Thailand dan Saudi Arabi. Dan makam Syekh Muhammad Arsyad al-Banjari yang dikeramatkan dan dikunjungi ribuan penziarah setiap harinya di daerah Kalampayan Kecamatan Astambul Kabupaten Banjar.

Meneliti sastra lisan menurut Endraswara (2018) tidak terlepas dari aspek Budaya. Sastra lisan yang disampaikan dengan lisan, dari mulut ke mulut, mengukir budaya tertentu. Budaya merupakan hasil dari peristiwa dan keadaan historis yang berbeda dan bukan hanya produk lingkungan atau ras. Budaya atau peradaban, adalah keseluruhan kompleks yang mencakup pengetahuan, kepercayaan, seni, hukum, moral, kebiasaan, dan kemampuan, serta kebiasaan lainnya yang diakuisisi oleh manusia sebagai anggota masyarakat (hlm. 225-229). Meneliti sastra lisan sama dengan meneliti budaya masyarakat pemilik sastra lisan. Meneliti budaya tidak akan terlepas dari tradisi yang ada di masyarakat. Menurut Endraswara (2018), kata kunci dari tradisi adalah memori, seleksi, kelanjutan, pengulangan, dan penemuan (hlm. 235). Pembacaan manaqib Syekh Muhammad Arsyad al-Banjari di masyarakat Banjar adalah seni ingatan yang secara kontinuitas terus diulangulang, sehingga menyebabkan memori tentang Syekh Muhammad Arsyad alBanjari tetap terpelihara dan terwariskan pada generasi berikutnya.

\section{LANDASAN TEORI}

\subsection{Pengertian Legenda}

Sastra lisan adalah karya sastra yang disebarkan secara lisan dari generasi ke generasi. Sastra lisan biasanya bercirikan mempunyai beberapa ciri, yakni: (1) sifatnya 
tradisonal, muncul dari masyarakat yang tidak melek huruf, dan masih polos; (2) tidak mempunyai pencipta dan melukiskan budaya kolektif masyarakat tertentu; (3) adanya pesan yang ingin disampaikan, bersifar humor dan khayalan. Hal yang utama dalam sastra lisan adalah isi, dan pesan yang ingin disampaikan yang biasanya tidak tersurat, tetapi tersirat dalam sastra lisan tersebut. Selain itu, dampak sosial karya sastra itu merupakan hal terpenting dalam sastra lisan. (Wellek \& Warren, 1995: 111).

Teeuw (1984, hlm. 10) mengatakan bahwa dalam sastra lisan manusia Indonesia berusaha untuk mewujudkan hakikat dirinya sendiri bahkan sampai sekarangpun. Untuk manusia zaman sekarang, sastra lisan itu tetap bernilai dan berfungsi apabila dia berusaha mencari makna dan nilai bagi dirinya sebagai manusia.

Danandjaya (Danadjaya, 2002, hlm.22--152) mengkalisfikasi enam jenis tradisi lisan beserta dalam berbagai suku di Indonesia, yaitu 1), ungkapan tradisional, 2) bahasa rakyat 3) sajak dan puisi rakyat, , 4) pertanyaan tradisional 5) nyanyian rakyat dan 6) cerita prosa rakyat.

Bascom (dalam Danadjaya, 2002) membagi prosa rakyat menjadi tiga kelompok besar, yakni (1) legenda (legend), (2) mite (myth), dan (3) dongeng (folktale) (hlm.50). Berbeda dengan mite yang ditokohi dewa dan dianggap suci, legenda merupakan cerita rakyat yang ditokohi manusia, mempunyai sifat-sifat luar biasa, kelebihan dan juga peristiwa luar biasa. Tempat terjadi legenda adalah tempat seperti yang dikenal sekarang. (Djamaris, 1990, hlm. 99--100).

Bruvard (dalam (Danadjaya, 2002, hlm. 67) mengklasifikasikan legenda menjadi empat macam, yaitu (1) legenda keagamaan (religious Legend), (2) Legenda alam gaib (supernatural legends), (legenda perseorangan (personal legend), (4) legenda setempat (local legend). Legenda Syekh Muhammad Arsyad merupakan legenda keagamaan.

\subsection{Etnografi}

Hanifah (2010) menyatakan bahwa Etnografi adalah ilmu yang digunakan untuk mendiksripsikan, memaparkan, dan menganalisis budaya susatu suku bangsa. Etnografi merupakan cabang dari antropologi. ( hlm. 1). menurut Koentjaraningrat (2014) etnografi merupakan deskripsi menyeluruh kebudayaan etnik suku bangsa (hlm. 12).

Oleh karena itu, dapat disimpulkan bahwa penelitian etnografi berfokus pada aspek kebudayaan pada suatu suku bangsa, yaitu dengan melihat lokalitas-lokalitas pada kebudayaan tersebut.

\subsection{Tinjauan Definisi dan Konsep Etnografi}

Menurut Spradley (2007) etnografi tidak sekedar meneliti masyarakat, tetapi bahkan belajar dari masyarakat, yaitu dengan mengambil pelajaran hikmah dari kebudayaan tersebut (hlm. 3). Duranti (1997) menyatakan bahwa, etnografi adalah penjelasan secara tertulis mengenai simbol, karaktersitik, aktivitas, organisasi social dari masyarakat tertentu. (hlm. 85). Pada dasarnya perhatian utama penelitian etnografi adalah tentang the way of life suatu masyarakat. Esensi penelitian etnografi tidak hanya mengambil simpulan dari kebudayaan masyarakat saja, tetapi juga 
mengambil hikmah dan pelajaran sosial dari kebudayaan tersebut.

Etnografi merupakan metode khusus yang memuat karakteristik dan bentuk tertentu, termasuk partisipasi etnografer (peneliti etnografi) untuk melihat, mendengar, dan memahami kehidupan sehari-hari (Setyowati, 2006, hlm. 36). Oleh karena itu, seorang etnografer sebagai bentuk pengamatan dan pengambilan data di lapangan, harus terlibat langsung dalam kehidupan keseharian

\section{Koentjaraningrat}

menjelaskan tentang kerangka penjelasan yang lebih rinci mengenai etnografi, karena etnografi yang memuat bahan mengenai kesatuan kebudayaan suatu komunitas suku bangsa berdasarkan geografi, ekologi, atau wilayah administratif yang menjadi yang dibagi ke dalam bab-bab dengan urutan yang baku, (hlm. 2-3).

Menurut Hanifah (2010) untuk memberika penjelasan yang lengkap dan menyeluruh, penelitian etnografi biasanya bersifat holistik-integratif (Hanifah, 2010, hlm. 2; lihat juga Mulyana, 2001, hlm. 161).

Sebuah budaya telah dianggap holistic-integratif apabila terdiri atas bagian-bagian yang tidak dapat terpisahkan karena interaksi bagianbagian dari kebudayaan telah menyatu (Mantja, 2007, hlm. 7).

Etnografi juga memiliki karakteristik seperti; pertama, menggali atau meneliti secara mendalam fenomena sosial terjadi didalam masyarakat tertentu. Kedua, perolehan data yang tidak terstruktur akibat dari perbedaan persepsi antar personal dan kelompok sosial. Ketiga, kasus atau sampel sedikit, karena penelitian etnografi menggunakan pendekatan induktif, artinya kesimpulan yang didapat didasarkan dari yang khusus menjadi umum. Keempat, dilakukan analisis data dan interpretasi data tentang arti dan tindakan manusia (human action). Hal yang paling menarik dari etnografi adalah menarik simpulan atas prilaku dan sikap sosial dari suatu masyarakat tertentu (Atkinson \& Hammersley, 1994, hlm. 250).

Menurut Ahimsa Putra telaah etnografi di Indonesia, didasarkan pada gaya penulisannya, sehingga menyimpulkan empat tipe etnografi, di antaranya; etnografi awam, laci (positivisme), analisis, dan kritis (Ahimsa-Putra, 1987, hlm. 8).

Untuk memudahkan dalam penagamatn fenomena social dan interpretasi data yang didapat, seorang peneliti etnografi harus terlibat langsung dalam waktu yang lama dalam masyarakat tersebut.

Dalam penelitian sastra lisan, Crapanzano (dalam Endraswara, 2018) memberikan rambu-rambu bahwa etnografer harus mendeskripsikan aspek budaya dalam sastra lisan, dalam hal ini adalag legenda Syekh Muhammad Arsyad al-Banjari (hlm. 211).

\section{METODE PENELITIAN}

Penelitian ini merupakan penelitian kualitatif. Metode yang digunakan dalam penelitian ini adalah metode etnografi. Penelitian ini menguraikan Syekh Muhammad Arsyad al-Banjari mitos-mitos dan keramat yang dipercaya masyarakatnya, budaya yang ada didalamnya, dan pengaruh legenda Syekh Muhammad Arsyad al-Banjari pada masyarakatnya. Metode etnografi adalah strategi pencapaian etnigrafi 
Legenda Syekh Muhammad Arsyad Al-Banjari danPengaruhnya

pada Masyarakat Banjar (Dede Hidayatullah)

dalam mendiskripsikan sesuatu dari lapangan penelitian sastra lisan. Metode etnografi adalah strategi pendiskripsian pola-pola komunikasi suatu suku bangsa di wilayah tertentu. Etnografi sastra lisan berarti pendeskripsian sastra lisan berdasarkan pemahaman entitas (Endraswara, 2018, hlm. 211). Dengan metode etnografi ini dapat diperoleh Legenda Syekh Muhammad Arsyad alBanjari, mitos dan keramat dan pengaruhnya terhadap masyarakat Banjar.

Data primer penelitian ini adalah cerita tentang Syekh Muhammad Arsyad al-Banjari didapat dari wawancara dengan tokoh masyarakat, dan manaqib Syekh Muhammad Arsyad al-Banjari. Sedangkan data sekunder dari penelitian ini adalah buku-buku legenda cerita rakyat seperti buku Sastra Lisan Banjar (1978) hasil penelitian Sunarti, et al. dan buku-buku lain yang berhubungan dengan penelitian ini.

Dari semua data tersebut, peneliti menguraikan secara singkat cerita Syekh Muhammad Arsyad al-Banjari. Setelah itu, medeskripsikan perjalanan hidupnya dan keramat Syekh Muhammad Arsyad al-Banjari. peneliti kemudian menguraikan pengaruh yang muncul dari legenda Syekh Muhammad Arsyad al-Banjari masyarakat Banjar.

\section{HASIL DAN PEMBAHASAN 4.2 Legenda Syekh Muhammad Arsyad al-Banjari}

Syekh Muhammad Arsyad al-Banjari adalah galar Maulana Syekh Muhammad Arsyad bin Abdullah Al-Banjari. Sidin lahir 15 Shafar 1122 $H$ atawa 19 Maret $1710 M$ di Kampung Lok Gabang, wan maninggal di Dalam Pagar 6 Syawwal $1227 \mathrm{H}$ atawa dengan 13 Oktober 1812 M baumur 105 tahun wan dikuburakan di Kalampayan, kacamatan Astambul, kabupatin
Banjar (kurang labih $56 \mathrm{Km}$, matan Banjarmasin).

Syekh Muhammad Arsyad Al-Banjari adalah ulama nang sangat bawiwaba wan bapangaruh. Sidinlah nang bausaha banar wan paling baparan dalam kisah sajarah pengembangan agama Islam di Kalimantan sampai ka saluruh nusantara. Syekh Muhammad Arsyad Al-Banjari orang nang gigih banara mampertahankan wan mangembangkan faham Ahlus Sunnah wal Jama'ah, yaitu tauhid nang bapingkut lawan faham Asy'ariah wan Maturidiyah, wan Mazhab Imam Syafi'i biwang Ilmu Fiqih, wan tasawuf bapingkut ajaran Junaidi al-Bugdadi. Sidin jua katuju manulis kitab sagan diajarkan lawan masyarakat.

Waktu halus, Syekh Muhammad Arsyad Al-Banjari bangaran Muhammad Ja'far. Sidin anak panuhanya lima bawangsanak katurunan Abdullah dengan Siti Aminah. Dangsanak sidin nang lain; Haji Muhammad Arsyad; Haji Zainal Abidin; Abidin; Diang Panangah; dan Normin.

Waktu baumur 7 tahunan, Muhammad Arsyad kacil fasih banar mambaca Al-Qur'an. Sampai-sampai sultan maangkat anak lawan sidin karna takjub lawan bacaan wan jua lukisan sidin nang asri banar, lalu sidin dibawa ka istana sagan dilajari ilmu lainnya.

Bakat wan kapintaran Syekh Muhammad Arsyad kalihatan banar. Lalu Sultan manulakakan sidin ka Makkah sagan mempelajari ilmu agama pas baumur usia 30 tahun. Sultan baharap, ilmu nang didapat Syekh Muhammad Arsyad di Tanah Suci itu kawa dilajarakan lagi lawan urang Banjar nang ada di banua. Sakira urang Banjar batambah jua pengetahuan agama wan ibadahnya.

Di Tanah Suci Makkah wan Madinah, sidin mangaji lawan ulama masyayikh nang masyhur wan terkanal waktu ngintu, nang kaya Syekh Athaillah bin Ahmad Al-Mishri Al-Azhar, Syekh Muhammad bin Sulaiman Al-Kurdi, Madinah. Sidin sampat manulis kitab nang bangaran fatawa Sulaiman Kurdi hasil mangaji baduaan wan batakun masalah pajak nang ada di karajaan Banjar. Syekh Muhammad bin Sulaiman AlKurdi digalari orang Syaikhul Islam Imamul Haramain nang kala itu datang matan Mesir, sidin ini yaitu Syekh Muhammad Sulaiman AlKurdi adalah pengarang kitab Hawasyil Mawaniyyah syarah $\mathrm{Ba}$ Fadal masalah fiqih, 
Syekh Muhammad bin Abdu Karim As-Sammany Al-Mawanny dalam ilmu tasawuf sidin mendapat ijazah tammah sagan maajarakan wan maijazahakan tareqat sammanaiyah wan manjadi Khalifah tammah jua dari Syekh Muhammad bin Abdu Karim As-Sammany Al-Mawanny, Syekh Ahmad bin Abdul Mun'im Ad-Damanhuri, Syekh Sayyid Abdul Faydh Muhammad Murtadha'Az-Zabidi, Syekh Hasan bin Ahmad'Akisy Al-Yamani, Syekh Salim bin Abdullah Al-Bashri, Syekh Shiddiq bin Umar Khan, Syekh Abdullah bin Hijazi bin AsySyarqawi, Syekh Abdurrahman bin Abdul Aziz AlMaghrabi, Syekh Sayyid Abdurrahman bin Sulayman Al-Ahdal, Syekh Abdurrahman bin Abdul Mubin Al-Fathani, Syekh Abdul Ghani bin Syekh Muhammad Hilal, Syekh'Abid As-Sindi, Syekh bdul Wahab Ath-Thanthawi, Syekh Maulana Sayyid Abdullah Mirghani, Syekh Muhammad bin Ahmad Al-Jawahir, Syekh Muhammad Zayn bin Faqih Jalaluddin Aceh.

Waktu di Makkah, Syekh Muhammad Arsyad Al-Banjari bakawal wan baangkatan dingsanak lawan panuntut-panuntut ilmu setanah air lainnya, nang kaya: Abdul Wahhhab Bugis Sailikin matan Makassar, Abdus Samad matan Palembang (pengarang kitab Siyarus Salikin wan Hidayatus Salikin) wan Abdur Rahman Masri matan Betawi (Jawa). Konon manurut kisah di Makkah itu, sidin sawat jua bakawan wan Datu Sanggul (Abdus Samad), sidin diberi kitab nang masyhur bangaran Kitab Barencong olih Datu Sanggul.

Tiga puluh tahunan labih mangaji di makkah wan madinah, Syekh Muhammad Arsyad Al-Banjari kawa manguasai banyak biwang ilmu agama, nang kaya: ilmu fiqih, ilmu tasawuf, usul fiqih, Bahasa Arab, nahwu, sharaf, balaghah, wan lain-lain, lalu ilmu falak (astronomi), matematika, wan ilmu umum nang kaya seperti ilmu politik serta pamarintahan. Kada awas imbah ngintu sidin bapadah wan guru sidin nangbangaran Syekh Sulaiman Kursi handak manyambung mangaji lagi di Mesir. Tapi jar guru sidin, baik bulik haja maajar di nusantara maamalakan ilmu. Akhinya empat sekawan matan tanah Jawi bulik ka kampung halamannya masing-masing.

Imbah lawas di jalan, buhannya ngintu sapai di tanah Betawi (Jakarta.) Syekh Muhammad Arsyad wan kawan-kawan disambut oleh para ulama wan orang banyak dengan gembira. Kurang labih 60 hari bamadam di Betawi (Jakarta), sidin bajalanan ka babarapa masigi. Berkat beberapa karamah (kaahlian) nang sidin miliki, sidin dapat membetulkan arah kiblat masjid nang kurang pas arahnya. Mesjid nang sidin baiki arah kiblatnya antaranya Mesjid Jembatan Lima, Mesjid Luar Batang, wan Mesjid Pekojan.

Pada bulan Ramadhan 1186 H (1772 M) sampai sidin di tanah Banjar. Kadatangannya disambut mariah oleh karajaan wan seluruh rakyat Banjar.

Syekh Muhammad Arsyad dianggap raja matan bahari sudah jadi kulawarga karajaan, jadi sidin dapat jua tanah pambagian Sultan Tahmidullah II di luar kota Martapura, di higa sungai martapura. Tanah ngini sidin ulah jadi kampung wan jadi majlis jua madrasah sagan maajar ilmu nang sidin dapat di Makkah Madinah.

Syekh Muhammad Arsyad banyak jua manulis kitab. Ada nang ringkas ngarannya risalah. Ada jua nang panjang ngarannya kitab. Awanang gasan umum, ada jua gasan khusus (urang nang sidin liat sudah pas dapat ilmu ngintu). Ada nang sagan lalakian wan bibinian, ada jua nang khusus sagan bibinian haja. Kitab karangan sidin ni ada nang mamadahakan labih dri 35 kitab, tapi nang masyhur wan mu'ntabarah wan ada kitabnya sampai wahini, nang kaya:

1. Sabilal Muhtadin. Baisi fiqih.

2. Risalah Ushuluddin. Kitab tauhid bahasa melayu tulisan Arab nang ditulis tahun $1188 \mathrm{H}$.

3. Tuhfatur Raghibin. Baisi tentang tauhid nang ditulis tahun $1188 \mathrm{H}$.

4. Kanzul Ma'rifah. Baisi tentang ilmu tasawufwan Nur Muhammad.

5. Luqthatul'Aljan. Kitab khusus sagan babinina nang membahas fiqih bibinan.

6. Kitab Faraid. Baisi cara babagi waris.

7. Al-Qawlul Mukhtashar nang mabahasa kisah Imam Mahdi. Ditulis tahun 1196 H.

8. Kitab Ilmu Falak. Baisi ilmu falaq atawa astronomi.

9. Fatawa Sulayman Kurdi. Baisi tentang fatwa-fatwa guru sidin Sulayman Kurdi bakaitan lawan pajak nang dipungut olih kerajaan Banjar. 
10. Kitabun Nikah. Baisi cara bakakawinan dalam hukum Islam.

Selain itu, pula karya tulis sidin berupa mushaf Al-Qur'an tulisan tangan sidin dalam ukuran besar wan khat nang sangat indah, t erdiri dari 3 jilid. Satiap jilidnya sapuluh juz haja. sampai wahini quran ini masih kawa dilihat nang sajilid di Museum Nasional Lambung Mangkurat Banjarbaru Kalimantan Selatan.

Kitab-kitab karangan Syekh Muhammad Arsyad sampai wahini masih dijadiakan kajian wan dilajarakan, serta dijadikan kitab rujukan dalam baibadah, nang utama kitab Sabilal Muhtadin. Kitab Sabilal Muhtadin ini dilajarakan luas di Asia Tenggara bahkan sampai ka Makkah wan Mesir. Ini merupakan salah satu karamah (kemuliaan) sidin.

\subsection{Karamah Syekh Muhammad Arsyad al-Banjari}

Syekh Muhammad Arsyad alBanjari mempunyai beberapa karamah seperti.

1. Ketika masih kecil, sewaktu beliau tidur di istana, badannya terangkat kurang lebih sehasta.

Diceritakan bahwa ketika Syekh Muhammad Arsyad al-Banjari sudah tinggal di istana kerajaan Banjar, Syekh Muhammad Arsyad al-Banjari mempunyai karamah pada waktu kecil, yaitu badannya terangkat kira-kira sehasta atau kurang lebih 1,5 meter dari tempat tidur.

Wayah suatu malam awak Muhammad Arsyad halus taangkat pas waktu guring kira-kira sahasta matan wadah kaguringan di istana.

Pangawal wan buhan menteri di istana pada malam itu takejut banar melihatnya, imbahtu dipingkutilah oleh menteri akan bawan Tuan Syekh Muhammad Arsyad, sidin pun terbangun manangis. Lalu pangawal istana bakisah hal itu kepada sidin. Sidin pun menjawab bahwa sidin tadi rahatan bamimpi batemu lawan orang tuha nang handak membawa sidin ka atas langit. Imbah kajadian nang luar biasa nagintu Sultan batambah sayang lawan sidin wan jua sidin dapat kaistimiwaan nang liwar di istana.

'Pada suatu malam ketika beliau sedang tidur, badan beliau terangkat kira-kira sehasta dan tempat tidur di Istana. Pengawal dan para menteri di Istana pada malam itu sangat terkejut sekali melihatnya dan kemudian memeganglah oleh menteri akan badan Tuan Syekh Muhammad Arsyad, beliau pun terbangun dan menangis. Kemudian pengawal Istana pun menceritakan hal itu kepada beliau, beliau pun menjawab bahwa beliau sedang bermimpi bertemu dengan seorang tua yang hendak membawa beliau ke atas langit. Maka dengan terjadinya keajaiban tadi Sulthan pun bertambah sayang terhadap beliau dan mendapat keistimewaan luar biasa di Istana.'

Peristiwa terangkatnya tubuh Syekh Muhammad Arsyad al-Banjari kecil ini sama dengan yang terjadi pada Sunan Giri kecil yang waktu itu masih bergelar Raden Samudera, di Padepokan Ampel Denta Ampel. Peristiwa ini menunjukkan bahwa beliau merupakan orang yang terpilih, dipilih dan diberi kemuliaan oleh Allah sejak kecil hingga masa tuanya. Dengan peristiwa ini juga membuat Sultan Tahmidullah semakin sayang kepada Syekh Muhammad Arsyad al-Banjari.

2. Membetulkan arah kiblat di Masjid Jembatan Lima Jakarta.

Setelah belajar beberapa tahun di istana, pada usia 30 tahun Syekh Muhammad Arsyad al-Banjari berangkat ke Haramain, yaitu Mekkah dan Madinah untuk menuntut ilmu. Di Haramain ini Syekh Muhammad Arsyad al-Banjari menghabiskan waktu selama 30 puluh tahun untuk belajar, 25 tahun 
di Mekkah dan 5 tahun di Madinah. Selama 30 tahun itu beliau banyak belajar tentang berbagai macam ilmu, seperti fiqih, tauhid, tasawuf, ilmu pendidikan, matematika, geografi dan astronomi. Bahkan beliau menguasai 33 macam ilmu tersebut. Ilmu yang biasa beliau ajarkan kepada anak cucunya adalah fiqih, tauhid, astronomi, dan tasawuf untuk golongan terbatas.

Setelah 30 tahun belajar di Haramain, beliau kemudian pulang, dengan mengambil rute persinggahan yang cukup banyak seperti Pattani (Tahiland), Aceh, Riau, Palembang,dan Betawi. Di Betawi ini beliau menemukan beberapa masjid yang arah kiblatnya kurang tepat menurut perhitungan ilmu falaq atau astronomi. Namun, masyarakat setempat tidak bisa menerima bahwa mesjid mereka tidak tepat arah kiblatnya. Akhirnya setelah berdebat dengan ilmu pengetahuan belum bisa meyakinkan masyarakat setempat bahwa arah kiblatnya kurang tepat, Syekh Muhammad Arsyad alBanjari kemudian mengangkat tapak tangannya, dari situ terlihat jelas ka'bah yang berada di Mekkah dan merupakan arah kiblat, dan ketidaktepatan arah kiblat masjid tersebut.

Di Betawi ngini sidin malihat ada masigit nang arah kiblatnya kurang pas manurut hitungan ilmu falaq atau astronomi. Lamun, masyarakat situ kada mau manarima mesjid buhannya salah arah kiblatnya alias kada pas ka kiblat arahnya. Lawas kalawasan bapandir ilmu falaq, lalu ai sidin maangkat talapak tangan, matan situ kalihatan banar ka'bah nang berada di Mekkah wan merupakan arah kiblat, wan kada pasnya arah kiblat masjid nangintu.

Barkat karamah (keahlian) nang sidin miliki, sidin kawa mambujurakan arah kiblat masigit nang kada pas. Masigit yang sidin baiki arah kiblatnya adalah Mesjid
Jembatan Lima, Mesjid Luar Batang, dan Mesjid Pekojan.

'Di Betawi ini, Syekh Muhammad Arsyad al-Banjari melihat masjid yang arah kiblat belum pas menurut ilmu falaq atau astronomi. Akan tetapi, masyarakat di sana tidak menerima kalau masjid itu salah arah kiblat, setelah dijelaskan dengan menggunakan ilmu falak, tetapi tidak menerima juga, belia kemudian mengangkat telapak tangannya. Dari situ terlihat secara nyata ka'bah di Mekkah yang merupakan arah kiblat dan melencengnya arah kiblat masjid itu.

Berkat beberapa karamah (keahlian) yang Syekh Arsyad miliki, beliau dapat membetukan arah kiblat masjid yang kurang tepat. Adapun Mesjid yang diperbaiki arah kiblatnya adalah Mesjid Jembatan Lima, Mesjid Pekojan, dan Mesjid Luar Batang.'

Karamat memperlihatkan ka'bah dari tapak tangan ini muncul setelah beliau menjelaskan secara rinci terlebih dahulu dengan menggunakan ilmu astronomi tentang ketidaktepatan arah kiblat masjid.

3. Mengetahui kedalaman lautan dari melihat warna permukaannya.

Karamah ini sebetulnya adalah kemampuan dan kepandaian, serta kecerdikan Syekh Muhammad Arsyad al-Banjari dalam melihat fenomena alam, yang didukung dengan pengetahuannya yang luas dalam bidang geografi, matematika, dan astronomi. Karamah Mengetahui kedalaman lautan dari melihat warna permukaannya ini bisa dilakukan oleh semua orang, asal orang tersebut sudah bisa mengenal fenomena alam dan menguasai paling tidak dua ilmu, yaitu ilmu astronomi dan ilmu geografi. Dalam karamah ini, ada hal lain 
yang menyebabkan bahwa pengetahuan, kemampuan, dan kepandaian, serta kecerdikan Syekh Muhammad Arsyad al-Banjari dalam melihat fenomena alam ini dimasukan dalam karamah ini. Hal itu adalah bahwasanya setiap ucapan Syekh Muhammad Arsyad al-Banjari ini dibuktikan dengan bukti empiris yaitu diukur langsung dengan menggunakan alat ukur, sehingga ketepatannya sangat akurat. Hal ini menunjukkan bahwa Syekh Muhammad Arsyad al-Banjari tidak sekedar mengira-ngira saja, tetapi memang mengetahui kedalaman lautan itu dengan anugerah Allah yang didukung dengan kemampuan dan kepandaian, serta kecerdikan Syekh Muhammad Arsyad al-Banjari dalam melihat fenomena alam, serta pengetahuannya yang luas dalam bidang geografi, matematika, dan astronomi.

Karamat yang ketiga ini merupakan karamat yang muncul ketika Syekh Muhammad Arsyad al-Banjari berhadapan dengan orang Belanda, dan beliau dicoba dengan berbagai hal yang tidak masuk diakal. Namun, dengan kemampuan dan karamat serta qudrat dari Allah, Syekh Muhammad Arsyad alBanjari bisa menghadapi orang Belanda yang menguji beliau tersebut, bahkan menjadikan orang-orang Belanda itu menghormati dan memuliakan beliau. Orang Belanda memberi gelar kepada Syekh Muhammad Arsyad al-Banjari dengan gelar 'Tuan Haji Besar'. Gelar ini menunjukkan rasa kagum dan hormat orang Belanda kepada Syekh Muhammad Arsyad al-Banjari.

\section{Pembahasan}

Seperti yang sudah disampaikan oleh Endraswara (2018), meneliti sastra tidak terlepas dari aspek budaya masyarakatnya. Sastra lisan yang disampaikan dengan lisan, dari mulut ke mulut, mengukir budaya tertentu. Demikian juga dengan legenda Syekh Muhammad Arsyad al-Banjari. Legenda Syekh Muhammad Arsyad al-Banjari adalah memori masyarakat Banjar yang terus diulang-ulang terutama pada saat pembacaan manaqib yang dilakukan setiap tahun secara rutin pada waktu wafatnya pada setial tanggal 6 Syawal. Selain itu, pembacaan manaqib ini juga dilakukan pada waktu yang lain yang tidak terikat dengan hari wafatnya. Pengulangan pembacaan manaqib secara kontinuitas ini membawa pengaruh yang kuat terhadap pembentukan budaya dan karakter orang Banjar khususnya orang Martapura dan garis keturunan Syekh Muhammad Arsyad alBanjari.

Ada beberapa hal yang bisa disimpulkan dari legenda Syekh Muhammad Arsyad al-Banjari yang mempengaruhi terhadap budaya dan karakter orang Banjar dan zurriyatnya.

Pertama, belajar dan mengajar sepanjang umur seperti yang diceritakan dalam Syekh Muhammad Arsyad alBanjari, bahwa pada umur 7 tahun beliau sudah dididik di istana kerajaan Banjar. Kemudian pada umur 30 tahun beliau melanjutnya pendidikannya di mekkah dan Madinah Selama 30 tahun. Hal ini membuat masyarakat Banjar khususnya Martapura dan zuriyatnya menjadi terpicu dan mengikuti langkah beliau untuk terus belajar menuntut ilmu. Ada beberapa ulama besar yang merupakan garis keturunannya seperti Mufti Jamaluddin, Abdurrahman Siddiq Safat Mufti Kerajaan Indragiri Hilir, Kyai Kasyful Anwar pendiri Pondok Pesantren Darussalam Martapura, Kyai Sya'rani Arif, seorang ahli hadis dan juga pimpinan pondok pesantren Darussalam 
1959-1969, dan Guru Sekumpul, serta masih banyak lagi ulama-ulama yang lain. kedua, terlihat geliat pertumbuhan pesantren di kabupaten Banjar pada khususnya dan Kalimantan Selatan pada umunya sebagai sarana dalam mencari ilmu agama seperti yang dilakukan oleh Syekh Muhammad Arsyad al-Banjari. Di Kabupaten Banjar sendiri, ada pesantren pertama yang dibangun oleh Syekh Muhammad Arsyad yang sekarang bernama Sullamul Ulum di desa Dalam Pagar. Kemudian ada pesantren Darussalam yang menjadi tujuan utama para santri. Lalu ada pesantren tahfiz Darussalam, pesantren takhasus Darussalam, pesantren Darul Makrifah, pesantren Hidayatullah Bincau, Pesantren Mangun Jaya, pesantren Annur Masykuriyah Sekumpul, dan lainlain. Yang ketiga, bahwa keramat yang yang dipunyai Syekh Muhammad Arsyad al-Banjari merupakan keramat atau mitos yang didasari dari sumber yang ilmiah. Keramat ini hanya sebagai penguat dari argumentasi yang disampaikan oleh Syekh Muhammad Arsyad al-Banjari sehingga lebih meyakinkan pada lawannya. Keramat bukanlah yang utama, istiqamah dalam belajar dan beribadah jauh lebih utama dan bermakna.

Sama dengan penelitian Laila (2014) yang meneliti fungsi cerita riwayat Datu Sanggul bagi masyarakat Banjar, sebagai sistem proyeksi, sebagai alat pengesahan kebudayaan dan sebagai alat penekan berlakunya tata nilai masyarakat Banjar, serta sebagai alat pendidikan. Bahkan, legenda Syekh Muhammad Arsyad al-Banjari bisa membentuk karakter orang Banjar, terutama orang Martapura, Kabuapten Banjar.
Seperti juga penelitian Hidayatullah, (2017) yang meneliti motif dan keramat legenda Datu Kabul yang mampu membuat membuat masyarakat sekitarnya mempercayai dan memperlakukan Mesjid Sungai Banar seperti ka`bah. Maka, penelitian ini juga mempengaruhi cara urang Martapura menjalani kehidupan dengan lebih mengutamakan, ilmu pengetahuan, dalam hal ini adalah ilmu agama.

\section{PENUTUP}

\section{Simpulan}

Legenda Syekh Muhammad Arsyad al-Banjari menceritakan belajar dan mengajar sepanjang hidup. Dimulai dari belajar di kerajaan Banjar sampai di Haramain, sesudah itu beliau mengajar sepanjang umurnya untuk masyarakat Banjar.

Syekh Muhammad Arsyad alBanjari mempunyai keramat yang didasari dari sumber yang ilmiah. Keramat ini bukanlah tujuan dari ilmu syekh Muhammad Arsyad al-Banjari, tetapi hanya sebagai penguat dari argumentasi yang disampaikan oleh Syekh Muhammad Arsyad al-Banjari sehingga lebih meyakinkan pada lawannya. Istiqamah lebih baik dari 1000 Keramat. istiqamah dalam menuntut ilmu dan beribadah lebih baik dan lebih utama.

Legenda Syekh Muhammad Arsyad al-Banjari merupakan legenda yang mempunyai pengaruh yang besar dalam membentuk karakter orang Banjar, terutama orang Martapura dan keturunnya. Legenda ini sangat membekas diingatan orang Martapura dan orang Kalimantan karena ada pengulangan yang kontinue yang dilakukan dengan pembacaan manaqib setiap tahunnya. legenda Syekh 
Muhammad Arsyad al-Banjari telah membentuk karakter orang Martapura menjadi orang yang suka menuntut ilmu agama, bahkan menjadi rujukan dalm ilmu agama di Kalimatan Selatan.

\section{DAFTAR PUSTAKA}

Ahimsa-Putra, H. S. (1987). Etnografi sebagai kritik budaya: Mungkinkan di Indonesia? Jerat Budaya, 1(1), 1-9.

Atkinson, P., \& Hammersley, M. (1994). Etnography and participant observation. In Handbook of Qualitative Research (pp. 249-261). Sage: Thousand Oak.

Danadjaya, J. (2002). Folklor Indonesia: Ilmu Gosip, Dongeng, dan lain-lain. Jakarta: Grafiti.

Danandjaja, J. (2002). Folklor ilmu gosip, dongeng, dll. jakarta: Pusaka Utama Grafiti.

Daud, A. (1997). Islam dan masyarakat banjar. Jakarta: PT. Raja Grafindo Persada.

Djamaris, E. (1990). Menggali Khazanah Sastra Melayu Klasik. Jakarta: Pustaka Jaya.

Duranti, A. (1997). Lingusitic anthropology. California: Cambridge University Press.

Endraswara, S. (2018). Antropologi sastra lisan: Perspektif, teori, dan praktik pengkajian (I). Jakarta: Yayasan Pustaka Obor Indonesia.

Hanifah, N. (2010). Penelitian Etnografi dan Penelitian Grounded Theory. Jakarta: Akademi Bahasa Asing Borobudor.

Hidayatullah, D. (2017). Legenda Datu
Kabul dan mesjid Sungai Banar: Analisis motif dan keramat. Undas, 13(1), 35-47. Retrieved from https://ojs.badanbahasa.kemdikbu d.go.id/jurnal/index.php/undas/is sue/archive

Koentjaraningrat. (2014). Pengantar ilmu antropologi. Jakarta: Rineka Cipta.

Laila. (2014). Fungsi Cerita Riwayat Datu Sanggul Bagi Masyarakat Banjar. In D. Hidayatullah, Saefuddin, W. Rakhman, \& N. Kurniasih (Eds.), Bunga Rampai Sastra tahun 2014 (1st ed., pp. 20-41). Banjarbaru: Balai Bahasa Kalimantan Selatan.

Mantja, W. (2007). Etnografi desain penelitian kualitatif pendidikan dan manajemen pendidikan. Malang: Elang Press.

Mulyana, D. (2001). Metodologi penelitian kualitatif: Paradigma baru ilmu komunikasi dan ilmu sosial lainnya. Bandung: PT. Remaja Rosdakarya.

Sam`ani, M., AsmoeniA. Rachman, Kusmartono, V. P. R., Hadijah, S., Kawi, D., Subaikto, B., ... (ed.), W. (2004). Sejarah Banjar (M. S. Ideham, Syarifuddin, G. Usman, Z. A. Anis, \& W. (ed.), Eds.). Banjarmasin: Badan Penelitian dan Pengembangan Daerah Provinsi Kalimantan Selatan.

Setyowati. (2006). Etnografi sebagai metode pilihan dalam penelitian kualitatif di keperawatan. Jurnal Keperawatan Indonesia, 10(1), 35-40. https://doi.org/10.7454/jki.v10i1.1 71

Spradley, J. P. (2007). Metode Etnografi. Yogyakarta: PT. Tiara Wacana Yogya. 
Teeuw, A. (1984). Sastra dan Ilmu Sastra: Pengantar Teori Sastra. Jakarta: Pustaka Jaya - Giri Mukti Pusaka.

Wellek, R., \& Warren, A. (1995). Teori Kesusastraan (4th ed.; M. Budianta, Ed.). Jakarta: Gramedia.

Yulianto, A., Jahdiah, Suminar, C., \& Hidayatullah, D. (2005). Tokoh Mitos dan Legendaris dalam Sastra Daerah Banjar: Suatu Analisis Semiotik. Banjarbaru. 